\title{
Benign Thalamic Neoplasm
}

National Cancer Institute

\section{Source}

National Cancer Institute. Benign Thalamic Neoplasm. NCI Thesaurus. Code C6222.

A benign neoplasm of the thalamus. 